\title{
Comparison of different models for predicting soil bulk density. Case study - Slovakian agricultural soils**
}

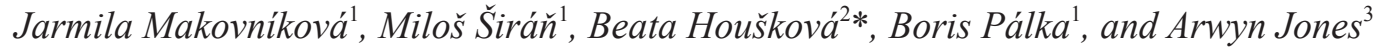 \\ ${ }^{1}$ National Agricultural and Food Centre, Soil Science and Conservation Research Institute Bratislava, Regional Station Banská \\ Bystrica, Mládežnícka 36, 97404 Banská Bystrica, Slovakia \\ ${ }^{2}$ National Agricultural and Food Centre, Soil Science and Conservation Research Institute Bratislava, Gagarinova 10, \\ Bratislava, Slovakia \\ ${ }^{3}$ Natural Capital Soil Project, European Commission, Joint Research Centre Sustainable Resources - Land Resources (D03), \\ Via Fermi 2749, 21027 Ispra (VA), Italy
}

Received July 17, 2017; accepted September 14, 2017

\begin{abstract}
Soil bulk density is one of the main direct indicators of soil health, and is an important aspect of models for determining agroecosystem services potential. By way of applying multi-regression methods, we have created a distributed prediction of soil bulk density used subsequently for topsoil carbon stock estimation. The soil data used for this study were from the Slovakian partial monitoring system-soil database. In our work, two models of soil bulk density in an equilibrium state, with different combinations of input parameters (soil particle size distribution and soil organic carbon content in \%), have been created, and subsequently validated using a data set from 15 principal sampling sites of Slovakian partial monitoring system-soil, that were different from those used to generate the bulk density equations. We have made a comparison of measured bulk density data and data calculated by the pedotransfer equations against soil bulk density calculated according to equations recommended by Joint Research Centre Sustainable Resources for Europe. The differences between measured soil bulk density and the model values vary from -0.144 to $0.135 \mathrm{~g} \mathrm{~cm}^{-3}$ in the verification data set. Furthermore, all models based on pedotransfer functions give moderately lower values. The soil bulk density model was then applied to generate a first approximation of soil bulk density map for Slovakia using texture information from 17523 sampling sites, and was subsequently utilised for topsoil organic carbon estimation.
\end{abstract}

Keyw ords: soil bulk density, pedotransfer function, texture, soil carbon content

\section{INTRODUCTION}

Soil bulk density is one of the main direct indicators of soil health (Abbott and Manning, 2015; Van der Biest et al., 2014). It also affects the soil biomass productivity and

\footnotetext{
*Corresponding author e-mail: b.houskova@vupop.sk

**This work was supported by the Slovak Research and Development Agency contract No. APVV-0098-12 and APVV-15-0160.
}

environmental quality (Lal and Kimble, 2001). Soil bulk density is a dynamic soil property, as it varies in time and space. It is influenced by crop and land management practices, as well as by natural processes such as the climate conditions that affect soil cover, organic matter levels, soil structure or porosity (Alletto and Coquet, 2009; Dam et al., 2005; Husnjack, 2002; Kumar et al., 2012; Logsdon, 2012; Norman et al., 2016; Timm et al., 2006; Veiga et al., 2008). Reversible processes in soils always tend to achieve an equilibrium state of soil bulk density (Makovníková and Širán̆, 2011), thus, at field capacity, and lacking external degradation influences, the bulk density of soil varies around the equilibrium. Such situation is referred to as the representative bulk density of soil. This directly depends on soil texture (Houšková, 2002). In practice, this value also depends on the type of soil use and intensity of cultivation. Soil bulk density is a very important parameter for evaluating the susceptibility of soil to compaction, as well as the intensity of compaction. Soil bulk density is also used in the quantification of soil carbon (C) stocks, and is therefore an important parameter for national inventories of greenhouse gas emissions, nutrients reserves and water balance. In addition, it is a parameter of models for determining agroecosystem services potential, especially provisioning and regulating services (Makovníková et al., 2017).

The determination of bulk density is not technically difficult, but the associated sampling is laborious and time consuming. This is because a sample of known volume must be extracted by a procedure that causes minimal

(C) 2017 Institute of Agrophysics, Polish Academy of Sciences 
disturbance (Lark et al., 2014; Suuster et al., 2011). This is also the reason why data sets for this property are limited compared to other soil characteristics. Therefore, there is a tendency to model bulk density values by means of pedotransfer functions or PTFs (Benites et al., 2007; Heuscher et al., 2005; Kaur et al., 2002; Suuster et al., 2011 Tranter et al., 2007) that are constructed from parameters that are routinely available in soil inventories, such as organic carbon and clay content (Benites et al., 2007; Bouma, 1989). These pedotransfer functions methods can also be used to assess other important soil parameters. Studies in Poland (Walczak et al., 2004) have been focused on the impact of soil physical and chemical parameters on the water retention curve and the water conductivity curve. The simplest models of representative soil bulk density use the texture triangle for mineral soils. This consists of a set of soil textural categories. Several authors worked with bulk density models based on pedotransfer functions (Adams, 1973; Bernoux et al., 1998; Federer, 1983; Gupta and Larson, 1979; Hermanz et al., 2000; Manrique and Jones, 1991; Rawls, 1983; Saxton et al.,, 1986; Tomasella and Hodnett, 1998).

The main aims of the study were (1) to model soil bulk density by the development of pedotransfer functions from measured data in existing databases, (2) to verify these models at monitoring sampling sites, (3) to apply the developed pedotransfer functions for the assessment and mapping of soil carbon stock, which is basic information for agro ecosystem services regulation.

\section{MATERIAL AND METHODS}

In this project, the empirical data on measured bulk density data, soil texture and organic carbon content were extracted from the partial monitoring system - soil database (PMS-S).

This database was generated via the soil monitoring system in Slovakia that has been running continuously since 1993. Its role is to provide and assess information on the spatial and temporal variability of soil parameters, as well as to generate an evaluation of soil quality. The monitoring network was based on ecological principles, taking into account land use, climatic regions, main soil types and subtypes, soil organic matter content, regions with emission problems, polluted and non-polluted regions. For this monitoring process, soil properties are observed every five years on agricultural soils at 312 sites. Furthermore, on 15 key sampling sites, selected soil properties are monitored on a yearly basis (Kobza et al., 2014). Soil sampling is done in June. At this time, in typical Slovakian climatic conditions, the bulk densities of the majority of soils are in balanced status. All samples are analysed by uniform analytical procedures (Kolektív, 2011). Additionally, the most significant indicators for soil threats are assessed according to the recommendation of European Commission (EC) for a unified soil monitoring system in Europe (Van Camp et al., 2004). This includes soil organic carbon content (dry way, using $\mathrm{CN}$ analyser), texture (modified to Slovakian databases content - particles $<0.001,<0.01$ and 0.001 $0.05,0.05-2.00 \mathrm{~mm}$ using the pipette method) and bulk density (core samples in $100 \mathrm{~cm}^{3}$ cylinders, dried at $105^{\circ} \mathrm{C}$ to constant weight, ISO 11272:1998). In total, empirical data for 262 sites from the monitoring database (texture, bulk density and organic matter content from the depth 0 $-10 \mathrm{~cm}$ ) were used for bulk density modelling (Table 1). Data from key sampling sites were also used to verify the pedotransfer model.

Statistical processing and interpretation of the results were done using the STATGRAPHIC Centurion IV software package, while graphical processing used ESRI ArcGis 10.3.1. In our work, measured bulk density acted as the dependent variable in the multiple regressions analysis, while soil properties served as the independent variables. Manrique and Jones (Manrique and Jones, 1991) have shown that partitioning of data by suborders is beneficial for purpose of the bulk density prediction. The soil bulk density models by Bernoux (1998) (pedotransfer equation: bulk density: $\mathrm{BD}_{\mathrm{B}}=1.398-0.0047$ clay $\left.-0.042 \mathrm{SOC}\right)$ and by Manrique and Jones (1991) (pedotransfer equation: $\left.\mathrm{BD}_{\mathrm{MJ}}=1.51-0.113 \mathrm{SOC}\right)$ are some of the models that are recommended by Joint Research Centre Sustainable

T a b l e 1. Summary statistics partial monitoring system - Soil database $(n=262)$

\begin{tabular}{|c|c|c|c|c|c|c|}
\hline Parameter & $\begin{array}{c}\text { Soil bulk } \\
\text { density }\left(\mathrm{g} \mathrm{cm}^{-3}\right)\end{array}$ & $\begin{array}{l}\text { Clay particles } \\
<0.01 \mathrm{~mm}\end{array}$ & $\begin{array}{c}\text { Clay } \\
<0.001 \mathrm{~mm}\end{array}$ & $\begin{array}{c}\text { Silt } \\
0.001-0.05 \mathrm{~mm}\end{array}$ & $\begin{array}{c}\text { Sand } \\
0.05-2.00 \mathrm{~mm}\end{array}$ & SOC $\%$ \\
\hline Average & 1.362 & 40.294 & 17.117 & 55.073 & 27.807 & 1.506 \\
\hline $\begin{array}{l}\text { Standard } \\
\text { deviation }\end{array}$ & 0.163 & 11.512 & 7.7886 & 13.691 & 16.221 & 0.890 \\
\hline $\begin{array}{l}\text { Coeff. of } \\
\text { variation in \% }\end{array}$ & 12.006 & 28.571 & 45.500 & 24.859 & 58.334 & 59.101 \\
\hline Minimum & 0.657 & 2.980 & 2.070 & 1.720 & 6.230 & 0.491 \\
\hline Maximum & 1.729 & 75.660 & 52.530 & 81.250 & 96.210 & 10.504 \\
\hline
\end{tabular}


Table 2. Analysis of variance for $\mathrm{BD}_{\mathrm{PTF}_{1}}$ and $\mathrm{BD}_{\mathrm{PTF}_{2}}$

\begin{tabular}{|c|c|c|c|c|c|c|c|c|c|c|}
\hline Source & $\begin{array}{l}\text { Sum of } \\
\text { squares }\end{array}$ & Df & $\begin{array}{l}\text { Mean } \\
\text { square }\end{array}$ & F-Ratio & P-value & $\begin{array}{l}\text { Sum of } \\
\text { squares }\end{array}$ & Df & $\begin{array}{l}\text { Mean } \\
\text { square }\end{array}$ & F-Ratio & P-value \\
\hline & & & $\mathrm{BD}_{\mathrm{PTF}_{1}}$ & & & & & $\mathrm{BD}_{\mathrm{PTF}_{2}}$ & & \\
\hline Model & 1.885 & 3 & 0.628 & 31.91 & 0.000 & 3.189 & 4 & 0.797 & 54.010 & 0.000 \\
\hline Residual & 5.099 & 259 & 0.019 & & & 3.793 & 257 & 0.014 & & \\
\hline $\begin{array}{l}\text { Total } \\
\text { (Corr.) }\end{array}$ & 6.985 & 262 & & & & 6.983 & 261 & & & \\
\hline
\end{tabular}

Resources (JRC) for use in Europe. Comparisons of these soil bulk density models with Slovakian models $\mathrm{BD}_{\mathrm{PTF}_{1}}$ and $\mathrm{BD}_{\mathrm{PTF}_{2}}$ were made.

\section{RESULTS AND DISCUSSION}

Based on the results of the partial component analysis (PCA), the following variables were selected for our pedotransfer models: silt content $0.001-0.05 \mathrm{~mm}$ in $\%$ (P), sand content $0.05-2.00 \mathrm{~mm}$ in $\%(\mathrm{~S})$, content of particles $<0.01 \mathrm{~mm}$ in \% (Ilc) and soil organic carbon content in $\%$ (SOC). As measured parameters for the models, we used textural data as categorized traditionally $(0.01 \mathrm{~mm}$ for clayey particles), as we wanted to utilise the original database created in the 1960s - the complex soil survey database. This incorporated soil texture data from 17523 sampling sites for the whole territory of Slovakia. Two main components have been extracted - as these had eigen values greater than or equal to 1.0. Together, they account for $78.29 \%$ of the variability in the original data (content of clayey particles $<0.01 \mathrm{~mm}$ (ILc) and silt content 0.001 $0.05 \mathrm{~mm}$ in $\%(\mathrm{P})$ ). The main components have been complemented by silt, sand and SOC. Calhoun et al. (2001) found that particle size distribution and SOC generally explain more than $60 \%$ of the variation in bulk density.

The analysis of variance for models and pedotransfer functions (262 empirical data were used) are reported in Tables 2 and 3. Figures 1 and 2 show measured bulk density in relation to predicted values. The statistical results show that model $\mathrm{BD}_{\mathrm{PTF}_{2}}$, based on organic carbon content (SOC), gives a more precise estimation of bulk density. This was affirmed by the lower statistical dispersion of values around the line (Fig. 1).

Soil bulk density pedotransfer models:

PTF $1 \mathrm{BD}_{\mathrm{PTF}_{1}}=3.1482-0.0118 \mathrm{ILc}-0.017 \mathrm{~S}-0.0152 \mathrm{P}$

Model BD together with SOC:

PTF $2 \mathrm{BD}_{\mathrm{PTF}_{2}}=2.662-0.0076 \mathrm{ILc}-0.0102 \mathrm{P}-$
Table 3. Analysis of variance for $\mathrm{BD}_{\mathrm{PTF}_{1}}$ and $\mathrm{BD}_{\mathrm{PTF}_{2}}$

\begin{tabular}{ccccc}
\hline PTF & $\begin{array}{c}\text { R-squared } \\
(\%)\end{array}$ & $\begin{array}{c}\text { R-squared } \\
\text { (adjusted } \\
\text { for d.f.) } \\
(\%)\end{array}$ & $\begin{array}{c}\text { Durbin- } \\
\text { Watson } \\
\text { statistic }\end{array}$ & P-value \\
\hline $\mathrm{BD}_{\mathrm{PTF}_{1}}$ & 26.989 & 26.144 & 1.772 & 0.032 \\
$\mathrm{BD}_{\mathrm{PTF}_{2}}$ & 45.671 & 46.825 & 1.678 & 0.000 \\
\hline
\end{tabular}

Since the P-value in the ANOVA table is less than 0.05, there is a statistically significant relationship between the variables at the $95 \%$ confidence level.
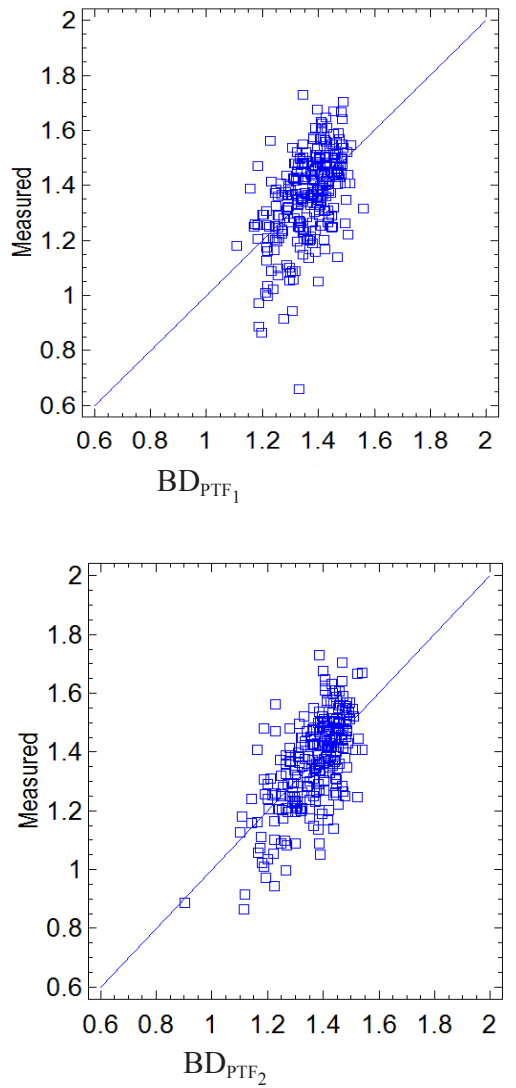

Fig. 1. Measured values versus predicted values $\left(\mathrm{BD}_{\mathrm{PTF}_{1}}, \mathrm{BD}_{\mathrm{PTF}_{2}}\right)$. 


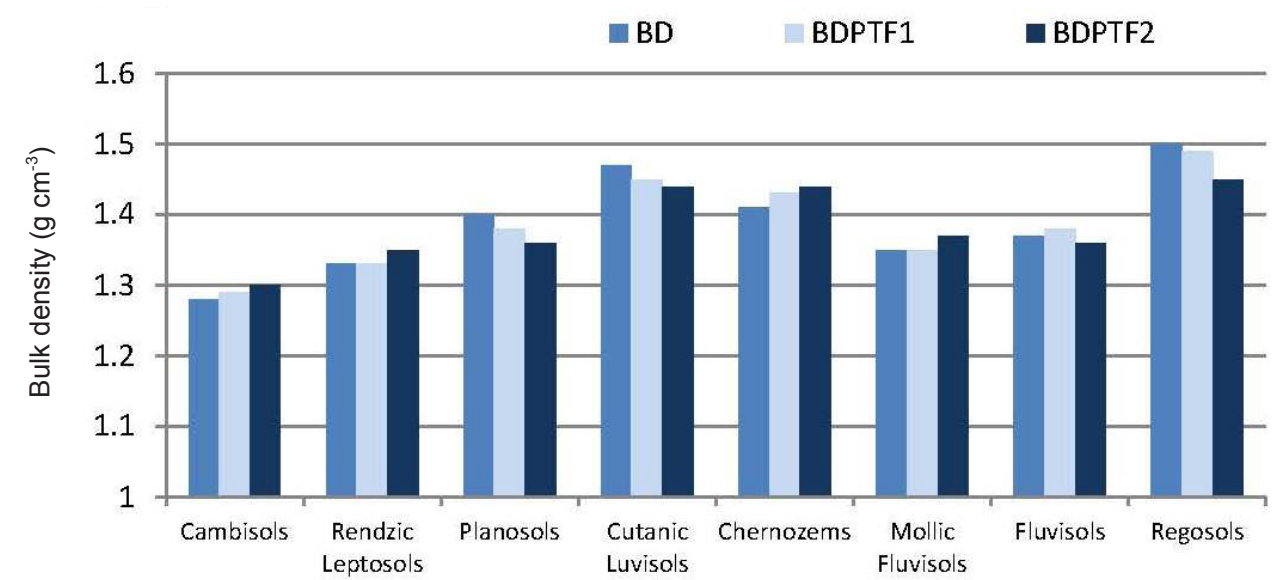

Fig. 2. Comparison between observed bulk density $(\mathrm{BD})$ and predicted values of soil bulk density $\left(\mathrm{BD}_{\mathrm{PTF}_{1}}, \mathrm{BD}_{\mathrm{PTF}_{2}}\right)\left(\mathrm{g} \mathrm{cm}^{-3}\right)$ in $\mathrm{main}$ soil types SR.

T a b l e 4. Comparison between measured bulk density and predicted values $\mathrm{BD}_{\mathrm{PTF}_{1}}, \mathrm{BD}_{\mathrm{PTF}_{2}}\left(\mathrm{~g} \mathrm{~cm}^{-3}\right)$

\begin{tabular}{lccc}
\hline $\begin{array}{l}\text { Statistical } \\
\text { parameter }\end{array}$ & $\mathrm{BD}$ & $\mathrm{BD}_{\mathrm{PTF}_{1}}$ & $\mathrm{BD}_{\mathrm{PTF}_{2}}$ \\
\hline Average & 1.362 & 1.362 & 1.363 \\
$\begin{array}{l}\text { Standard } \\
\text { deviation }\end{array}$ & 0.163 & 0.084 & 0.110 \\
$\begin{array}{l}\text { Coeff. of } \\
\text { variation } \\
(\%)\end{array}$ & 11.986 & 6.227 & 8.139 \\
$\begin{array}{l}\text { Minimum } \\
\text { Maximum }\end{array}$ & 0.657 & 1.107 & 0.574 \\
\hline
\end{tabular}

Since the P-value in the ANOVA table is less than 0.05, there is a statistically significant relationship between the variables at the $95.0 \%$ confidence level.

The values of bulk density of agricultural soils from Slovakia range between 1.2-1.6 $\mathrm{g} \mathrm{cm}^{-3}$ (Kobza et al., 2014). Despite the fact that the $\mathrm{BD}_{\mathrm{PTF}_{2}}$ model explains a higher percentage of the variation than model $\mathrm{BD}_{\mathrm{PTF}_{1}}$, this model shows stronger predictive power for modelling within soil types (Fig. 2).

The model was validated using a data set consisting of 15 key sampling sites of PMS-S database which were different from those used to generate the equations. The set of key sampling sites represents the six dominant soil types of Slovakia (Cambisols, Stagnosols, Planosols, Fluvisols, Chernozems, Luvisols) with a rather wide range of agrochemical properties. A comparison of measured bulk density (BD) and soil bulk density as calculated by the pedotransfer equations $\left(\mathrm{BD}_{\mathrm{PTF}_{1}}\right.$ and $\mathrm{BD}_{\mathrm{PTF}_{2}}$ ) following the updated input parameters that have been evaluated in the PMS-S database (Table 5, Fig. 3) were made. Bulk density
T a b l e 5. Summary of statistics of measured bulk density and model values of soil bulk density (key sampling sites, $n=15$ )

\begin{tabular}{lccccc}
\hline $\begin{array}{l}\text { Statistical } \\
\text { parameter }\end{array}$ & $\mathrm{BD}$ & $\mathrm{BD}_{\mathrm{PTF}_{1}}$ & $\mathrm{BD}_{\mathrm{PTF}_{2}}$ & $\mathrm{BD}_{\mathrm{B}}$ & $\mathrm{BD}_{\mathrm{MJ}}$ \\
\hline Average & 1.360 & 1.365 & 1.321 & 1.284 & 1.235 \\
$\begin{array}{l}\text { Standard } \\
\text { deviation }\end{array}$ & 0.089 & 0.090 & 0.123 & 0.110 & 0.038 \\
$\begin{array}{l}\text { Coeff. of } \\
\text { variation } \\
\text { (\%) }\end{array}$ & 6.544 & 6.606 & 9.287 & 8.604 & 3.047 \\
Min & 1.240 & 1.215 & 1.060 & 1.039 & 1.173 \\
Max & 1.534 & 1.526 & 1.487 & 1.416 & 1.344 \\
\hline
\end{tabular}

values calculated according to Bernoux et al. (1998) $-\mathrm{BD}_{\mathrm{B}}$ and to Manrique and Jones (1991) $\mathrm{BD}_{\mathrm{MJ}}$ (recommended by JRC for Europe) for comparison.

Sampling sites 6 to 8 are utilized as permanent grasslands, the rest of the sampling sites are of arable land. We found that models based on pedotransfer functions generally slightly lower the value of bulk density (with the exception of sampling sites 3, 9, 10 and 13 (Fig. 3)). Moreover, the best prediction of $\mathrm{BD}$ in the set of key sampling sites was from the $\mathrm{BD}_{\mathrm{PTF}_{1}}$ model, according to the average values, together with minimum and maximum values (Table 6). The differences between measured soil bulk density and the model values vary from -0.144 to $0.243 \mathrm{~g} \mathrm{~cm}^{-3}$. Furthermore, the average value of differences between the measured soil bulk density and the model values varies from 0.002 to 0.129 - and increases in the order: $\mathrm{BD}_{\mathrm{PTF}_{1}}<$ $\mathrm{BD}_{\mathrm{PTF}_{2}}<\mathrm{BD}_{\mathrm{MJ}}<\mathrm{BD}_{\mathrm{B}} . \mathrm{BD}_{\mathrm{PTF}_{1}}$ gave results closest results to the measured values. Barros and Fearnside (2015) in their work also describe lower values of bulk density in comparison with regional models. It is clear that locally generated equations will provide better estimations of soil bulk density, thus models $\mathrm{BD}_{\mathrm{PTF}_{1}}$ and $\mathrm{BD}_{\mathrm{PTF}_{2}}$ are more suitable for 


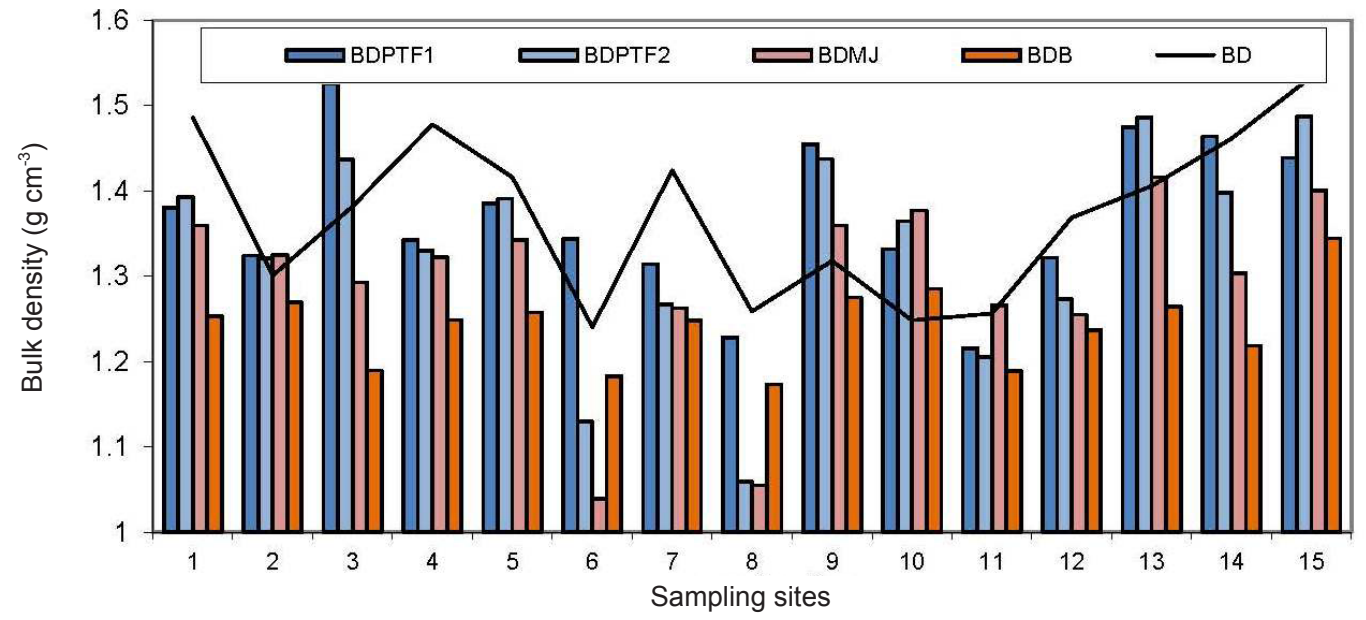

Fig. 3. Comparison between measured bulk density and bulk density values calculated by pedotransfer models $\left(\mathrm{BD}_{\mathrm{PTF}_{1}}, \mathrm{BD}_{\mathrm{PTF}_{2}}, \mathrm{BD}_{\mathrm{B}}\right.$, $\left.\mathrm{BD}_{\mathrm{MJ}}\right)$.

T a b l e 6. Summary of statistics of soil bulk density in topsoil of Slovakia

Soil bulk density $\left(\mathrm{g} \mathrm{cm}^{-3}\right)$

\begin{tabular}{ll}
\hline Average & 1.301 \\
Median & 1.301 \\
Standard deviation & 0.113 \\
Coeff. of variation (\%) & 8.685 \\
Minimum & 0.730 \\
Maximum & 1.810 \\
\hline
\end{tabular}

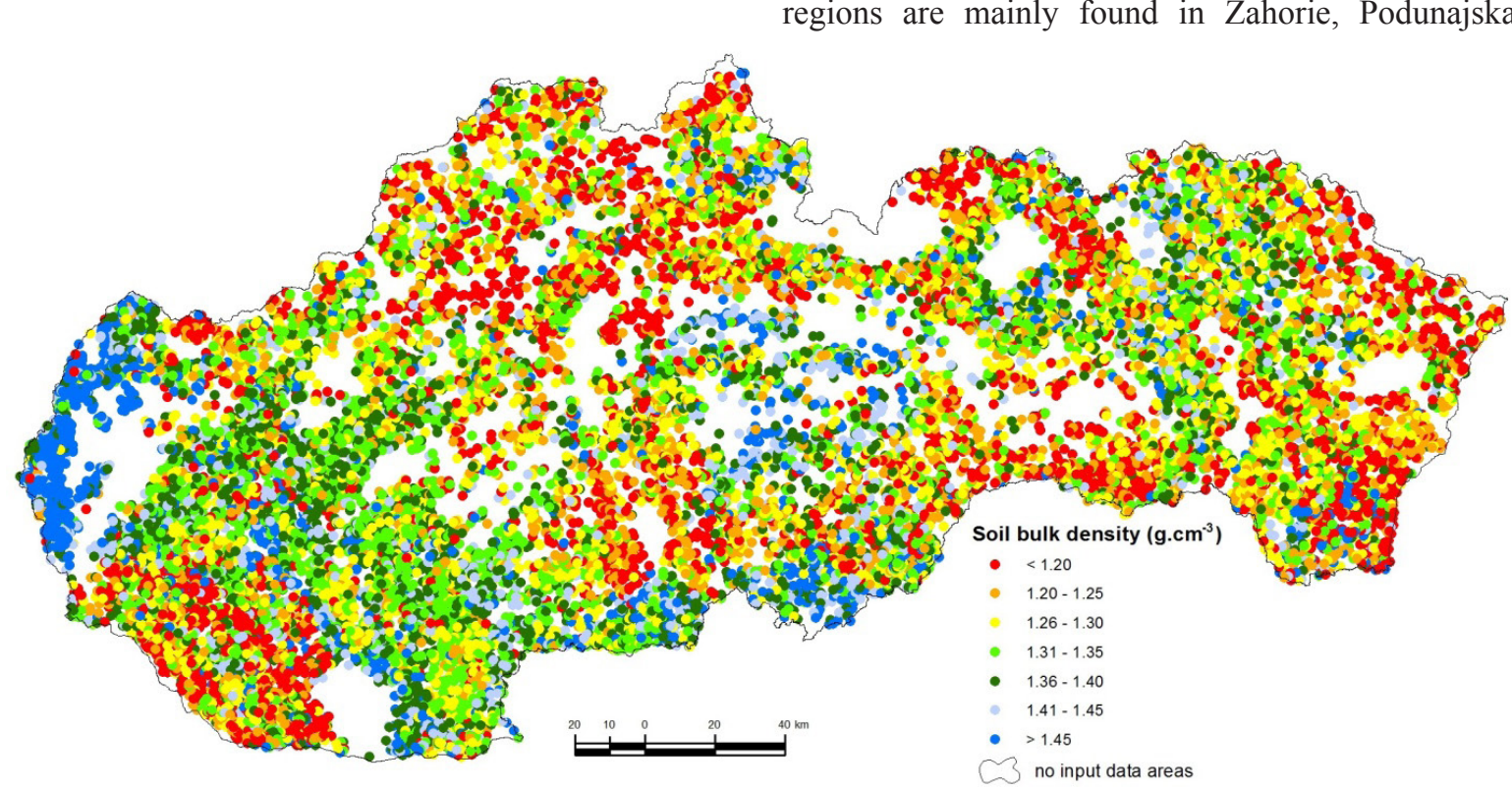

Slovak soils. According to Adams (1973), Rawls (1983), Federer (1983), Tomasella and Hodnett (1998), Manrique and Jones (1991) and Bernoux et al. (1998), the differences between measured and modelled BD values are in the range of 0.010 to $0.380 \mathrm{~g} \mathrm{~cm}^{-3}$.

The soil bulk density model $\left(\mathrm{BD}_{\mathrm{PTF}_{1}}=3.14816\right.$ $0.0118028 \mathrm{ILc}-0.0169725 \mathrm{~S}-0.0152297 \mathrm{P})$ that was used for the preparation of the soil bulk density map of Slovakia (Fig. 4), utilised soil textural data from 17523 sampling sites held in the complex soil survey database. The original paper database was transformed into a digital version by Skalský and Balkovič (2002).

Model values of representative bulk density for agricultural soils are presented in Fig. 4. The higher values of bulk density are located in regions with a greater representation of light (sandy and sandy-loamy) soils. These regions are mainly found in Zahorie, Podunajska and

Fig. 4. Bulk density of agricultural soils. 


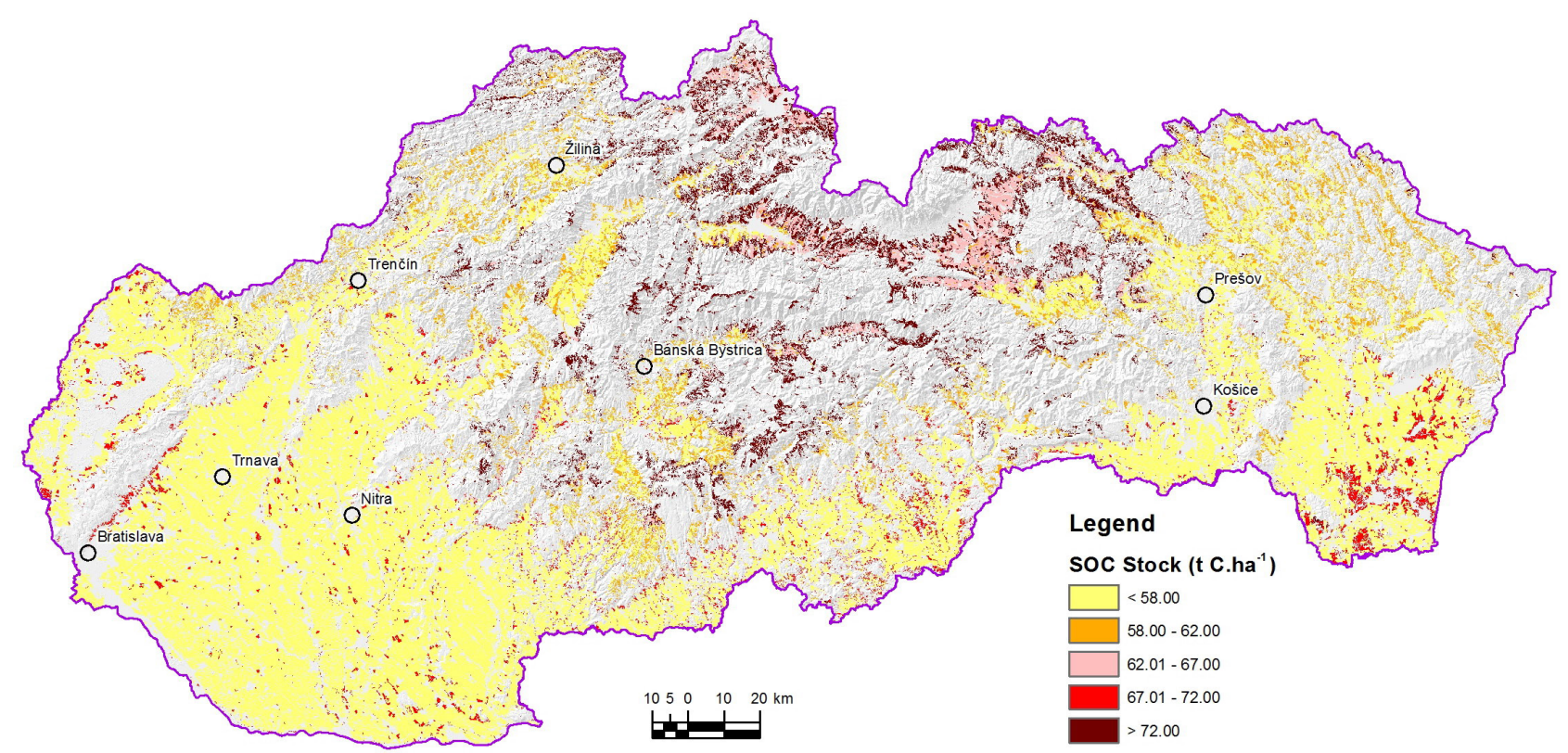

Fig. 5. Soil organic carbon stock in topsoil of agricultural soils.

Vychodoslovenska nizina (lowland), and also partly in the flysh region and Juhoslovanska kotlina (hollow basin). The lowest BD values have been observed in regions with heavy soils (predominantly clay loamy and clayey soils). These findings are in accordance with the measured values of bulk density for individual soil types and representative soil textural categories (Houskova, 2002). From such representative values, it is possible to assess the susceptibility of soils to compaction. Sandy soils are the most resistant, have the lowest susceptibility to compaction, in comparison with heavy clayey soils. The latter have the highest susceptibility to compaction even when exposed to lower loads. They are so-called 'minute soils', with very narrow intervals of suitable water content (around field capacity) for cultivation (Houškova, 2008).

In general, topsoil is considered to be the most important soil layer according to the carbon content (Taalab et al., 2013), which generally decreases with the depth. The map of topsoil carbon stock for agricultural soils in Slovakia (depth $0-30 \mathrm{~cm}$ ) was prepared using the $\mathrm{BD}_{\mathrm{PTF}_{1}}$ model and actual values of SOC from the CMS-P database monitoring database (Fig. 5). It should be noted that data obtained from $\mathrm{BD}_{\mathrm{PTF}_{1}}$ model have been elaborated further using the ROTh C model for estimation of carbon stock (Barančíková et al., 2010). Average carbon stock in soils in the depth $0-30$ $\mathrm{cm}$ in Slovakia is seen to range between 59 to $67 \mathrm{t} \mathrm{C}^{-1}$, depending on altitude. Lower amounts are typical for areas with altitude $0-300 \mathrm{~m}$ above sea level and higher for areas with altitude above $600 \mathrm{~m}$ above sea level (Širáň et al., 2013). This method is used to report national soil carbon inventories.

\section{CONCLUSIONS}

1. Using multiregression methods a distributed prediction of soil bulk density was produced. This was subsequently used in topsoil carbon stock determination.

2. It was created and compared pedotransfer models of bulk density that employed available empirical soil data.

3 . These models generally generate slightly decreased predicted bulk density values, in comparison with measured ones.

4. The utilisation of models in the verification set showed good prediction capacity for bulk density also in the case of soils with high variation of input data.

5 . The soil bulk density model was used for preparation of first approximate soil bulk density map for Slovakian agricultural soils. The data obtained from pedotransfer model have been further elaborated using the Rothamsted carbon model, so as to generate an estimation of carbon stock in topsoil layer for Slovakian agricultural soils map.

Conflict of interest: The Authors do not declare conflict of interest.

\section{REFERENCES}

Abbott L.K. and Manning D.A.C., 2015. Soil health and related ecosystem services in organic agriculture. Sustainable Agric. Res., 4(3), 116-125. http://dx.doi.org/10.5539/sar. v4n3p116

Adams WA., 1973. The effect of organic matter on the bulk \& true densities of some uncultivated podzolic soils. J. Soil Sci., 24, 10-17.

Alletto L. and Coquet Y., 2009. Temporal and spatial variability of soil bulk density and near-saturated hydraulic conductivity under two contrasted tillage management systems. Geoderma, 152, 85-94. 
Barančíková G., Makovníková J., Skalský R., Tarasovičová Z., Nováková M., Halás J., Gutteková M., Koco, Š. 2011. Influence of soil-ecological characteristics on development of organic carbon on arable soils of Slovakia. Soil Water Res., 5(1), 1- 9 .

Barros H.S. and Fearnside P.M., 2015. Pedo-transfer functions for estimating soil bulk density in central amazonia. R. Bras. Ci. Solo, 39: 397-407.

Benites V.M., Machado P., Fidalgo E.C.C., Coelho R.M., and Madari E.B., 2007. Pedotransfer functions for estimating soil bulk density from existing soil survey reports in Brazil. Geoderma, 139: 90-97.

Bernoux M., Arrouays D., Cerri C., Volkoff B., and Jolivet C., 1998. Bulk densities of Brazilian Amazon soils related to other soil properties. Soil Sci. Soc. America J., 162, 743-749.

Bouma J., 1989. Using soil survey data for quantitative land evaluation. In Adv. Soil Sci., 9, 177-213.

Calhoun F.G., Smeck N.E., Slater B.L., Bigham J.M., and Hall G.F., 2001. Predicting bulk density of Ohio soils from morphology, genetic principles, and laboratory characterization data, Soil Sci.Soc. Am. J., 65, 811-819.

Dam R.F., Mehdi B.B., Burgess M.S.E., Madramootoo C.A., Mehuys G.R., and Callum I.R., 2005. Soil bulk density and crop yield under eleven consecutive years of corn with different tillage and residue practices in a sandy loam soil in central Canada. Soil Till. Res., 84, 41-53.

Federer C.A., 1983. Nitrogen mineralization and nitrification. Depth variation in four New England forest soils. Soil Sci. Soc. America J., 47, 1008-1014.

Fulajtár E., 2006. Soil physical properties. SSCRI Bratislava, Slovak Republic.

Gupta S.C. and Larson W.E., 1979. A model for predicting packing density of soils using particle-size distribution. Soil Sci. Soc. Am. J., 43, 758-764.

Hermanz J.L., Peixoto H., and Cerisola C., 2000. An empirical model to predict soil bulk density profiles in field conditions using penetration resistance, moisture content and soil depth. J. Terramechanics, 37, 167-184.

Heuscher A.S., Brandt C.C., and Jardine M.P., 2005. Using soil physical and chemical properties to estimate bulk density data. Soil Sci. Soc. America J., 69, 51-56.

Houšková B., 2002. Assessment of the state of soil compaction in Slovakia. Advances in geoecology 35. A cooperating series of the IUSS. Catena Verlag, Germany, 379-386.

Houšková B., 2008. Natural susceptibility of soils to compaction (map). European Communities. http://esdac.jrc.ec.europa. $\mathrm{eu} /$.

Husnjack S., Filipović D., and Košutić S., 2002. Influence of different systems on soil physical properties and crop yield. Rostlinná výroba, 48(6), 249-254.

ISO 11272: 1998. Soil quality-Determination of dry bulk density

IUSS Working Group WRB, 2014. World Reference Base for Soil Resources 2014. International soil classification system for naming soils and creating legends for soil maps. World Soil Resources Reports No. 106. FAO, Rome.

Kaur R., Kumar S., and Gurung H.P., 2002. A pedotransfer function for estimating soil bulk density from basic soil data and its comparison with existing PTFs". Australian
Journal of Soil Research. 1. September, 2002, FindArticles. com. 11 Jan, 2011. http://findarticles.com/p/articles/mi hb3364/is 5 40/ai n31675919/

Kobza J., Barančíková G., Dodok R., Hrivňáková K., Makovníková J., Pálka B., Pavlenda P., Schlosserov, J., Styk J., and Širáň M., 2014. Monitoring pôd SR (Soil monitoring of Slovakia) (in Slovak). NPPC - VUPOP Bratislava, Slovak Republic.

Hrivňáková K., Makovníková J., Barančíková G., Bezák P., Bezáková Z., Dodok R., Chlpík J., Kobza J., Lištjak M., Mališ J., Píš V., Schlosserová J., Slávik V., Styk J., and Širáň M., 2011. Uniform analytical procedures for soil (in Slovak). Bratislava: VUPOP Bratislava, Slovak Republic.

Kumar S., Kadono A., Lal R., and Dick W., 2012. Long-term no-till impacts on organic carbon and properties of two contrasting soils and corn yields in Ohio. Soil Sci. Soc. America J., 76, 1798-1809.

Lal R. and Kimble J.M., 2001. Importance of Soil Bulk Density and Methods of Its Importance (Eds R. Lal, J.M. Kimble, R.F. Follett, B.A. Stewart). In: Assessment Methods for Soil Carbon, Lewis Publishers, London, UK.

Lark R.M., Rawlins B.G., Robinson D.A., Lebron I., and Tye A.M., 2014. Implications of short-range spatial variation of soil bulk density for adequate field-sampling protocols: methodology and results from two contrasting soils. European J. Soil Sci., 65, 803-814.

Logsdon S.D., 2012. Temporal variability of bulk density and soil water at selected field sites. Soil Sci., 177(5), 327-331.

Makovníková J., Pálka B., Širáň M., Kanianska R., Kizeková M. and Jad'ud'ová J., 2017. Modeling and evaluation of agroecosystem services (in Slovak). Banska Bystrica, Belianum, Slovak Republic.

Makovníková J. and Širáň M., 2011. Modelling of equilibrium soil bulk density (in Slovak). VUPOP Bratislava, Slovak Republic.

Manrique L.A. and Jones C.A., 1991. Bulk density of soils in relation to soil physical and chemical properties. Soil Sci. Soc. Am. J., 55, 476-481.

Norman C.R., Brye K.R., Gbur E.E., Chen P., and Rupe J., 2016. Long-term management effects on soil properties and yields in a wheat-soybean double-crop system in eastern Arkansas. Soil Sci., 181(1), 1-12.

Rawls W.J., 1983. Estimating soil bulk density from particle size analysis and organic matter content. Soil Sci., 135, 123-125.

Saxton K.E., Rawls W.J., Romberger J.S., and Papendick R.I., 1986. Estimating generalized soil-water characteristics from texture. Soil Sci. Soc. Am. J., 50(4), 1031-1036.

Skalský R. and Balkovič J., 2002. Digital database of selected soil profiles of complex soil survey of Slovakia (KPP-DB) (Ed. P. Jambor). Proc. Soil Science and Conservation Research Institute n. 25, Bratislava: SSCRI, Slovak Republic, 129-140.

Suuster E., Ritz Ch., Roostalu H., Reintam E., Kõlli R., and Astover A., 2011. Soil bulk density pedotransfer functions of the humus horizon in arable soils. Geoderma, 163, 74-82.

Širáň M., Makovníková J., and Barančíková G., 2013. Monitoring of soil bulk density - base for determination of soil organic carbon stocks (in Slovak), (Ed. B. Houšková) Proc. Soil Science and Conservation Research Institute n. 35, Bratislava: SSCRI, Slovak Republic, 141-148. 
Taalab K.P., R. Corstanje R., Creamer R., and Whelan, M.J., 2013. Modelling soil bulk density at the landscape scale and its contributions to $\mathrm{C}$ stock uncertainty. Biogeosciences, 10, 4691-4704.

Timm L.C., Pires L.F., Roveratti R., Arthur R.C.J., Reichardt K. Oliveira J.C.M., and Bacchi O.O.S., 2006. Field spatial and temporal patterns of soil water content and bulk density changes. Scientia Agricola, Piracicaba, 63(1), 55-64.

Tomasella J. and Hodnett M.G., 1998. Estimating soil water retention characteristics from limited data in Brazil. Soil Sci., 163, 190-202.

Tranter G., Minasny B., McBratney A.B., Murphy B., McKenzie N.J., Grundy M., and Brough D., 2007. Building and testing conceptual and empirical models for predicting soil bulk density. Soil Use and Management, 23(4), 437-443.

Van Camp L., Bujarrabal B., Gentile A-R., Jones R.J.A., Montanarella L., Olazabal C., and Selvaradjou S.K.,
2004. Reports of the Technical Working Groups established under the Thematic Strategy for Soil Protection. EUR 21319 EN/5. Office for Official Publications of the European Communities, Luxembourg.

Van der Biest K., D'Hondt R., Jacobs S., Landuyt D., Staes J., Goethals P., and Meire P., 2014. Ebi: An index for delivery of ecosystem service bundles. Ecological Indicators, 37(Part A): 252-265.

Veiga M., Reinert D.J., Reichert J.M., and Kaiser K.R., 2008. Short and long-term effects of tillage systems and nutrient sources on soil physical properties of a southern Brazilian Hapludox. Revista Brasileira de Ciência do Solo, 32, 1437 1446 .

Walczak R., Witkowska-Walczak B., and Sławiński C., 2004. Pedotransfer studies in Poland. In: Developments in Soil Science, Development of Pedotransfer Functions in Soil Hydrology. Elsevier, The Netherlands, 30, 449-464. 